\title{
關文讀後—兼談哲學問題與 哲學思考的本質
}

\author{
翁若愚
}

靈魂存在嗎? 如果靈魂存在, 人死後靈魂是否不滅? 自有文 明以來, 這兩個終極的問題一直揮之不去, 千百年來人們一直在 宗教、哲學的領域、科學的領域上探求切實的答案。關啟文教授 討論靈魂是否存在的文章 (下稱關文), 有兩個重要意義。首先 可以視關文為以哲學思考溝通、回應科學觀點與宗教觀念下另闢 一途的嘗試, 是一種有益有建設性的嘗試, 值得大家細讀, 探討 其成果。瀕死經驗的廣泛存在能否為靈魂的存在提供某種程度的 證據是一個重要的學術爭論, 涉及醫學科學與心理學的理論。瀕 死經驗的科學解釋與傳統的宗教觀念, 各有支持者。關文深入評 論許多有代表性的瀕死經驗的詳實案例, 為傳統的宗教觀點作出 有力的㦚護。關文的結論是, 雖然傳統的宗教觀念難以證明自己 的正確性, 不過自然主義的科學解釋也難以駁倒傳統的宗教觀 念。靈魂是否存在這一個重要的問題本質上就是一個跨學科的問 題。關文嘗試以哲學思考溝通科學解釋與傳統的宗教觀念, 對解 答靈魂是否存在的持續研究有積極的意義, 注入新的動力。

關文的第二個重要意義緊扣第一個重要意義。值得特別指出 的是透過以哲學思考溝通對瀕死經驗的科學解釋與傳統的宗教觀 念, 關文作出了哲學思考方法應用的一個良好示範。瀕死經驗的

翁若愚, 香港城市大學公共政策學系一級導師, 中國香港。

《中外醫學哲學》XIV:2 (2016 年) : 頁 61-64。

(C) Copyright 2016 by Global Scholarly Publications. 
爭論是科學解釋與傳統宗教觀念的爭論, 另一方面本質上也承傳 了哲學上二元論和唯物論之爭。關文在立場上沒有偏祖這兩層爭 論的任何一方, 他審視了生理學理論下的不同解釋, 如藥物作用、 缺氧等等。也審視了心理學理論下的解釋, 如個人信仰主觀投射、 人格解體效應等等。然後通過運用哲學思考與穆爾的相同及相異 方法把這些科學解釋暗藏的矛盾一一暴露出來。關文指出在思考 瀕死經驗的真實性時, 沒有必要在全盤接受與全盤否定之間作抉 擇。這個觀點是正確應用哲學思考方法處理瀕死經驗的堅實成 果。正如關文指出瀕死經驗的學術爭辯還會繼續, 需要有更多的 研究。哲學思考方法在這一個重要的學術爭論上, 應該大有可為。 在運用哲學思考方法探討靈魂是否存在時, 必須建基於溝通與尊 重科學觀點的基礎上，否則只能算是捕風捉影的玄思冥想。

單純運用哲學思考探索靈魂是否不朽，可以得出什麼結果？ 探討靈魂是否存在是哲學領域上一個早已經存在的問題。這方面 柏拉圖筆下的蘇格拉底在《裴多》對話錄提出的四個論證以證明 人死後靈魂不滅, 就是一個很好的例子。由於篇幅所限只列舉第 一及第二個論證作説明。

(1) 循環的論證(The Cyclical Argument 70c - 72e)

所有事物都從原來的一面走向相反的另一面。例如大的東西 原本就是從小的東西變成大。大小的狀態之間就是增加及減少的 過程。活着及死亡也是相反的兩個狀態, 死去及出生就是生死之 間的過程。活着的人慢慢死去, 就是由生走到死亡的過程。死了 的人又再次活過來, 就是由死亡走到生的過程。如果增加不能抵 銷減少的作用所有事物只有變得越來越小。但是實際上事物由大 變小, 也由小變大, 往復循環不息。所以人死後有輪迴, 靈魂離 開肉體, 然後又再次活過來。一切生命都是從死亡裏出生。

(2) 記憶的論證(The Argument from Recollection 72e - 78b)

人們看到相同的東西, 心裏就有了相等的這個概念。相等的 概念, 是一個抽象的概念, 超越了種種相等的事物, 一毫不差, 
完全相等。但是人們看到相等的東西卻並不是完全的相等。例如 兩塊石頭重量相等外型大小卻不一樣。人們看到這兩塊重量相等 的石頭, 就會想到或記起抽象的相等概念。這個抽象的相等概念 不能從經驗中獲得, 是先於經驗的概念。所以人們應該在出生之 前已經有這點知識了。也就只是説靈魂在我們出生之前已經存在 了。

這兩個論證各有明顯的弱點。首先循環的論證不能成立。因 為大小的相反, 與生死的相反是不同性質的相反。大小的相反有 程度之分, 有大一點、小一點。但是生死的相反就沒有程度之分。 生就是生死就是死, 沒有死多一點或生多一點之理。記憶的論證 假設了認識就是記憶的理論, 又假設靈魂在我們出生之前已經存 在並且對世界有認識。有人認為柏拉圖讓筆下的蘇格拉底論證靈 魂不朽, 目的是把輪迴從傳統的宗教信念提升為哲學上站得住腳 的信念。也有人認為柏拉圖透過筆下的蘇格拉底表述了他自己關 於靈魂、生死、輪迴的哲學理論。我認為這些理解都不對。柏拉 圖透過筆下的西米與齊貝, 挑戰了蘇格拉底的論證。明顯説明柏 拉圖自己本來就清楚知道這些論證有問題。我認為柏拉圖正是透 過蘇格拉底與西米及齊貝論證靈魂不滅的過程, 把當中潛藏的思 考問題都一一顯現出來。柏拉圖不認為蘇格拉底的論證確切無 誤, 讀者讀了就可以奉為金科玉律。柏拉圖對話錄內裡的論證本 質是探索性的, 並不是哲學教條。這個觀點在《裴多》裏就有支 持。柏拉圖透過西米的口, 表達了一些對哲學思考的觀察。大意 就是哲學思考處理的問題本來就是講不明白的問題。在這些問題 上要得到明確的知識根本就是非常困難甚至不可能。哲學家沒有 神聖的提示, 只有用哲學思考從各方面探索有關這些問題的一切 觀點, 不到水落石出決不罷休。如果最終也不能夠發現真相, 就 只能夠把最站得住腳的觀點當作是思考中的一條木筏, 在未知的 領域裡繼續探索。由此可見, 關文運用嚴謹的哲學思考方法審視 
瀕死經驗的科學解釋與宗教觀念，正切合柏拉圖對哲學問題與哲 學思考的深刻認識。

\section{參考文獻}

關啟文: 〈靈魂存在嗎? 一一瀕死經驗的啟示〉, 載陳強立編, 《中外 醫學哲學》, 2016 年, 第 14 卷, 第 2 期, 頁 7-41 KWAN Kai Man. "Does the Soul Exist? What Near-Death Experiences Reveal." International Journal of Chinese \& Comparative Philosophy of Medicine, edited by Jonathan Chan, 14:2 (2016), pp.7-41. 